\title{
CRITERIA
}

\section{Diagnosis of arrhythmogenic right ventricular dysplasia/cardiomyopathy}

\author{
William J McKenna, Gaetano Thiene, Andrea Nava, Fabrice Fontaliran, \\ Carina Blomstrom-Lundqvist, Guy Fontaine, Fulvio Camerini on behalf of the Task \\ Force of the Working Group Myocardial and Pericardial Disease of the European Society \\ of Cardiology and of the Scientific Council on Cardiomyopathies of the International \\ Society and Federation of Cardiology, supported by the Schoepfer Association
}

Correspondence to:

Prof William J McKenna, Department of Cardiological Sciences, St George's Hospital Medical School, Cranmer Terrace, London SW 17 ORE.

Accepted for publication 1 December 1993

Appendix: Members of the ARVD task force include: Saroja Bharati, 11745 SW Highway, Palos Heights, Illinois 60463, USA

Carina Blomstrom-Lundqvist, Department of Cardiology, University of Lund Hospital, S-221 85 Lund, Sweden. S-221 85 Lund, Sweden.
Fulvio Camerini, Department of Cardiology, Ospedale Maggiore, Piazza Ospedale 1, 34100 Trieste, Italy.

Domenico Corrado, Istituto di Anatomia Patologica,

Universita di Padova, 61 via $A$ Gabelli, 35121 Padova, Italy. Guy Fontaine, Service de Cardiologie, Hôpital JeanRostand, 39-41 rue Jean Le Galleu; 94200 Ivry-sur-Seine, Paris, France.

Fabrice Fontaliran, Service de Cardiologie, Hôpital Jean-

Rostand, 39-41 rue Jean Le

Galleu, 94200 Ivry-sur-Seine,

Paris, France.

Toru Iwa, Clinical

Electrophysiology, Internal

Medicine 3, Aichi Medical

College, Yazako, Nagajute-

College, Yazako, Nagajute-
cho, Aichigun 480-11, Japan.

cho, Aichigun 480-11, Japan.

Francesca Lobo, Departm
of Laboratory Medicine,

Hamilton Civic Hospital, 237

Barton Street East, Hamilton

Ontario L8L 2X2, Canada.

Robert Loire Hôpital Louis

Pradel, 28 avenue du Doyen

Lépine, 69500 Bron, France.

William McKenna,

Department of Cardiological

Department of Cardiological
Sciences, St George's Hospital

Medical School, Cranmer

Tedical School, Lranmer

Andrea Nava, Istituto di

Anatomia Patologica,

Universita di Padova, 61 via A

Gabelli, 35121 Padova, Italy.

Ryoso Okada, Research

Laboratory for Cardiovascular

Pathology, Juntendo

University, 2-1-1 Hongo,

Bunkyo-Ku, Tokyo 113,

Japan.

N Protonotarios, Medical

Center of Naxos, Hodical Naxos
Crotorios,

84300, Greece.

84300, Greece.
Peter Richardson, Cardiac

Department, King's College

Hospital, Denmark Hill,

London SE5 9RS.

Right ventricular dysplasia or cardiomyopathy is a heart muscle disorder of unknown cause that is characterised pathologically by fibrofatty replacement of the right ventricular myocardium. $^{1-5}$ Segmental right ventricular disease is usual, but evolution to more diffuse right ventricular involvement and left ventricular abnormalities with heart failure have been described..$^{6-10}$ The incidence is unknown. Clinical manifestations of the disease include structural and functional abnormalities of the right ventricle, electrocardiographic depolarisation/repolarisation changes, and presentation with sudden death or arrhythmias of right ventricular origin. The disease is often familial (about $30 \%$ ) with an autosomal dominant inheritance. ${ }^{112}$ It remains unclear whether this genetic background predisposes to a degenerative disease with atrophy and fibrofatty replacement of the right ventricular myocardium, or whether the inflammatory cells seen in approximately $25 \%$ of cases indicate an infectious or possibly genetically determined immune pathogenesis. ${ }^{13}$

Uncertainty concerning the pathogenesis of right ventricular dysplasia leads to the as yet

Criteria for diagnosis of right ventricular dysplasia I Global and/or regional dysfunction and structural
alterations ${ }^{17-23 \star}$

MAJOR

Severe dilatation and reduction of right ventricular ejection fraction with no (or only mild) LV impairment

Localised right ventricular aneurysms (akinetic or dyskinetic

areas with diastolic bulging)

Severe segmental dilatation of the right ventricle

MINOR

Mild global right ventricular dilatation and/or ejection fraction

reduction with normal left ventricle

Mild segmental dilatation of the right ventricle

Regional right ventricular hypokinesia

\section{Tissue characterisation of walls}

MAJOR

Fibrofatty replacement of myocardium on endomyocardial

biopsy

\section{Repolarisation abnormalities}

MINOR

Inverted $\mathrm{T}$ waves in right precordial leads (V2 and V3)

(people aged more than $12 \mathrm{yr}$; in absence of right bundle branch block)

^Detected by echocardiography, angiography, magnetic resonance imaging, or radionuclide scintigraphy. ECG, electrocardiogram; LV, left ventricle.

unresolved question of whether it is a single entity or the common end point of several disease processes. The familial nature of many cases has led to recognition that in any particular family the phenotypic expression of the disease can be very variable. In turn this leads to the need for criteria to delineate the spectrum of disease that justifiably can be called right ventricular dysplasia in clinical practice.

A definitive (gold standard) diagnosis of right ventricular dysplasia is based on histological demonstration of transmural fibrofatty replacement of right ventricular myocardium at either necropsy (figs 1 and 2) or surgery. ${ }^{1415}$ In most patients, however, assessment of transmural myocardium is not possible.

Diagnosis based on right ventricular endomyocardial biopsy specimens is inherently difficult because the segmental nature of the disease causes false negatives and because the interventricular septum is rarely involved. Biopsy specimens cannot reflect transmural changes and not infrequently in normal subjects there are islands of adipose tissue between myocytes in the right ventricle. Nevertheless the positive finding of fibrofatty
MAJOR

V Depolarisation/conduction abnormalities

Epsilon waves or localised prolongation (>110 ms) of the QRS complex in right precordial leads (V1-V3)

MINOR

Late potentials (signal averaged ECG)

\section{Arrhythmias}

MINOR

Left bundle branch block type ventricular tachycardia (sustained and non-sustained) (ECG, Holter, exercise testing).

Frequent ventricular extrasystoles (more than 1000/24 h)

Frequent
(Holter)

MAJOR

VI Family history

Familial disease confirmed at necropsy or surgery

MINOR

Familial history of premature sudden death $(<35 \mathrm{yr})$ due to suspected right ventricular dysplasia.

Familial history (clinical diagnosis based on present criteria) 
Ketty Schwartz, Unité INSERM 153, Pavillon Rambuteau, Hôpital de la Saltpetriere, 47 boulevard de l'Hôpital, 75013 Paris, France. Morie Sekiguchi, Department Cardiology, Shinshu University School of Medicine, Matsumoto City 390, Japan.

Furio Silvestri, Department of Morbid Anatomy, University of Trieste, Italy.

Gaetano Thiene, Istituto di Anatomia Patologica,

Universita di Padova, 61 via A Gabelli, 35121 Padova, Italy.

A Tsatsopoulou, Medical

Center of Naxos, Hora Naxos 84300, Greece. replacement of myocytes on biopsy can be a valuable diagnostic pointer. Diagnosis, however, relies heavily on the clinical demonstration of structural, functional, and electrophysiological abnormalities that are caused by or reflect the underlying histological changes.

Problems in the assessment of right ventricular structure and function, the multiple potential aetiologies of arrhythmias of right ventricular origin, and difficulties in the interpretation of the right ventricular endomyocardial biopsy have all made the establishment of definitive diagnostic criteria necessary. ${ }^{16}$ The importance of a common approach to diagnosis led to the development of the task force and the following proposals for the establishment of diagnostic criteria. These are based on the identification of structural abnormalities, fatty or fibrofatty replacement of the right ventricular myocardium, electrocardiographic changes, arrhythmias of right ventricular origin, and familial disease.

It is proposed that the diagnosis of right ventricular dysplasia would be fulfilled by the presence from different groups (table) of:

Two major criteria or

One major plus two minor criteria or

Four minor criteria
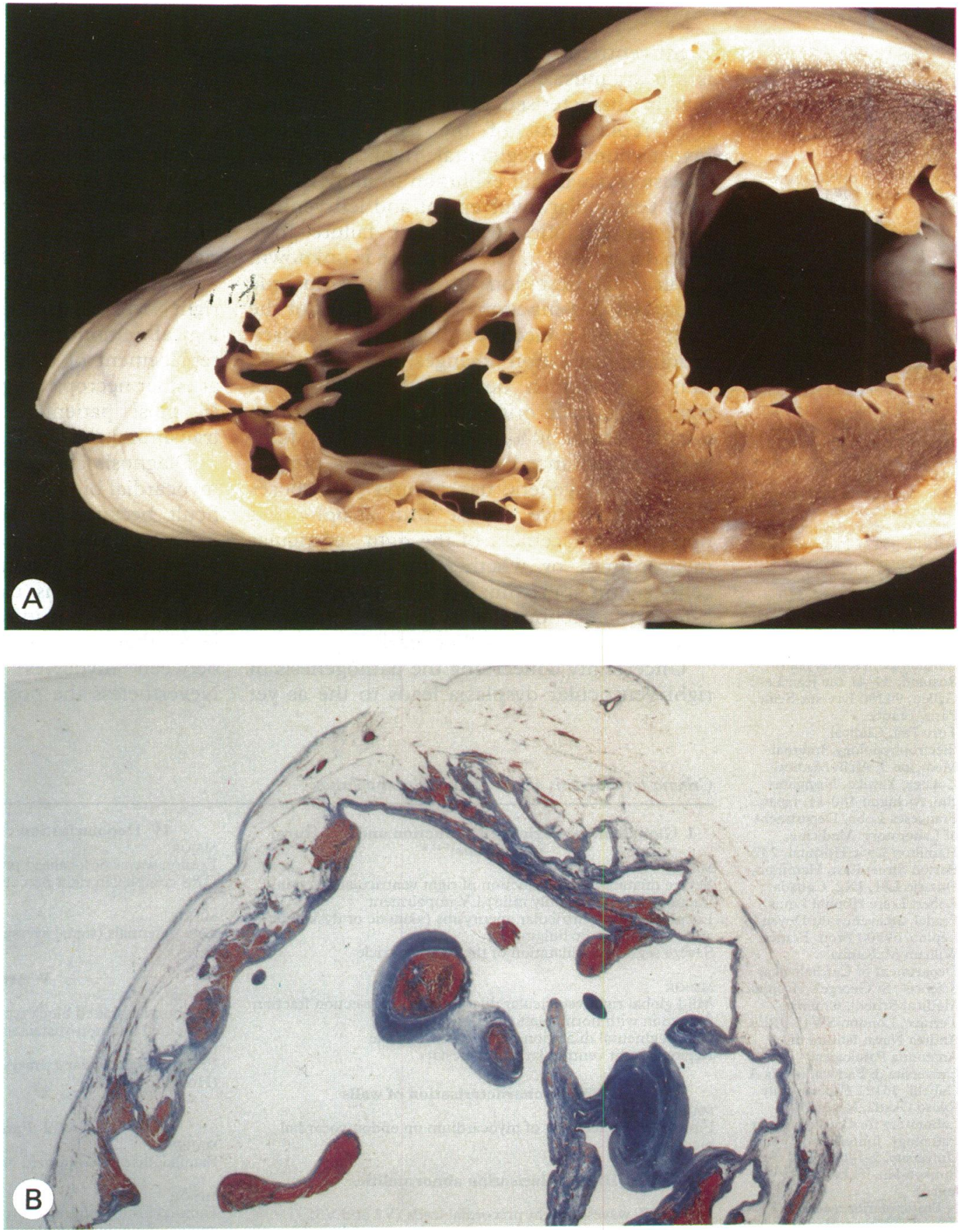

Figure 1 Necropsy findings in a 39 year old man with a family history of sudden death (two brothers) who had complex arrhythmia and died suddenly. (A) Cross section of the heart showing pronounced adipose infiltration of the right ventricular free wall and nearly normal left ventricle and ventricular septum. (B) Histological view of the right ventricular free wall showing myocardial atrophy and massive fibrofatty replacement. (Azan; original magnification, $\times 1$. ) 


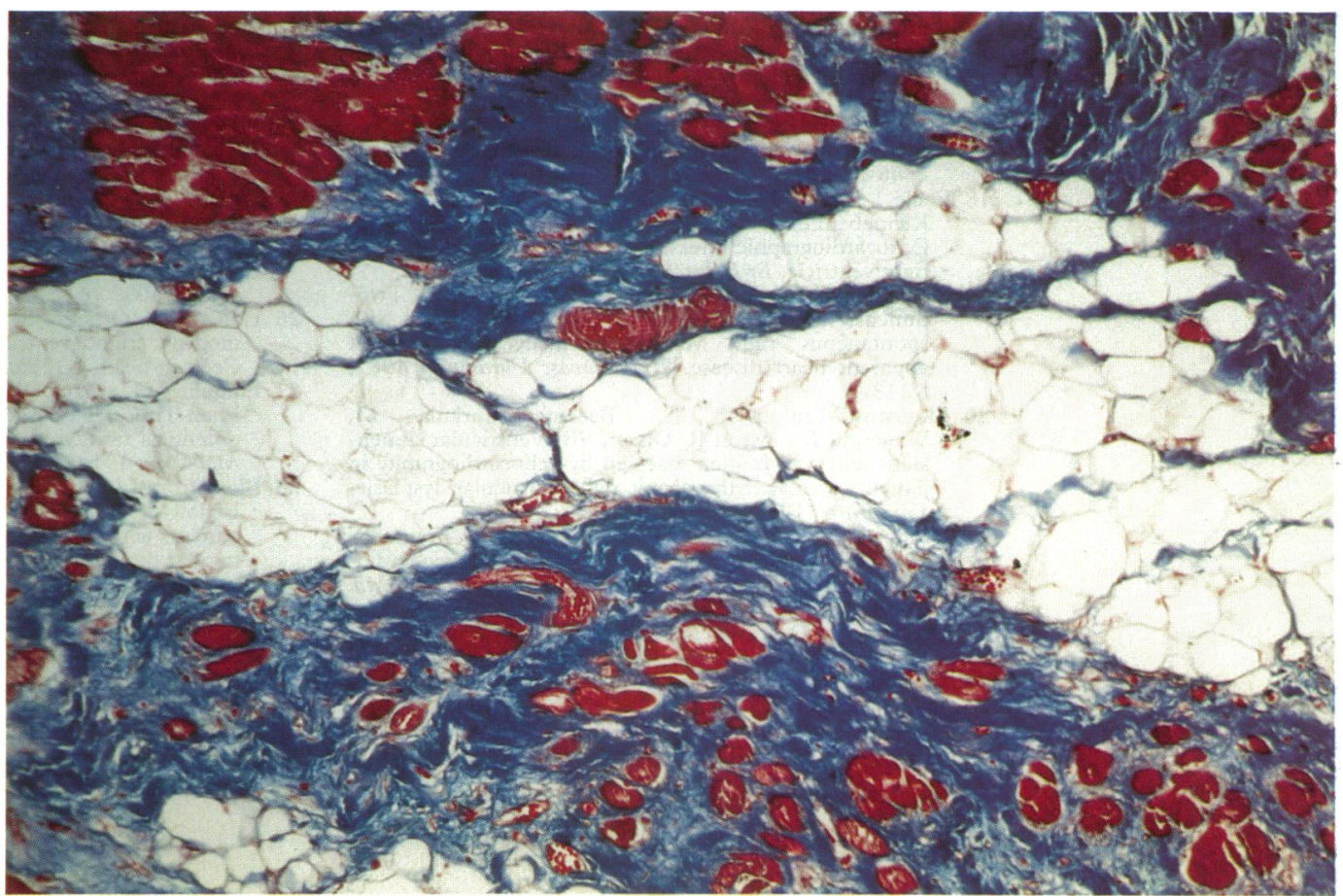

Figure 2 Histological view of the right ventricular free wall at high magnification, showing fibrofatty replacement. (Azan; original magnification, $\times 25$.)

Dilatation of the right ventricle or segments of the right ventricle is defined by echocardiographic or angiographic dimensions that are two to three (mild) or $\geqslant$ three standard deviations from normal. ${ }^{17-23}$ Problematic areas of interpretation are those where a subjective assessment is required, such as regional right ventricular dysfunction and structural alterations. Right ventricular endomyocardial biopsy on its own must be regarded as non-diagnostic, although when fibrofatty replacement is shown ${ }^{24}$ biopsy may help with in vivo histological validation of the clinical diagnosis. Experience with magnetic resonance imaging and ultra-fast computed tomography in the diagnosis of right ventricular dysplasia is limited and requires further evaluation. ${ }^{25}$; ; preliminary studies suggest that it may be possible to distinguish between fat and myocardium. Conventional definitions are used for epsilon waves, an abnormal signal averaged electrocardiogram based on time analysis, and ventricular arrhythmias. ${ }^{27-29}$

The diagnosis of arrhythmogenic right ventricular dysplasia based on the presence of major and minor criteria encompassing structural, histological, electrocardiographic, arrhythmic, and genetic factors is presented as a working framework to improve understanding of this condition. We expect that with increased pedigree ascertainment the potential identification of the gene(s) responsible, and a more detailed understanding of the natural history our concepts will evolve to either a more succinct clinico-pathological diagnosis or ideally a diagnosis based on a specific gene abnormality. At present, however, a common approach to diagnostic criteria for a phenotypic expression of right ventricular dysplasia will be essential, both to clinical management and to scientific progress.
1 Marcus FI, Fontaine GH, Guiraudon G, Frank R, Laurenceau JL, Malergue S, Grosgogeat Y. Right ventricular dysplasia. A report of 24 adult cases. Circulation 1982;65:384-98.

2 Fontaine G, Tereau Y, Frank R, Guiraudon G, Fillette F, Chomette G, Grosgogeat Y. Dysplasie ventriculaire droite arhythmogène et maladie de Uhl. Arch Mal Coeur droite arhythmogene et
Vaiss 1982;4:361-70.

3 Thiene G, Nava A, Corrado D, Rossi L, Pennelli N. Right ventricular cardiomyopathy and sudden death in young people. $N$ Engl f Med 1988;318:129-33.

4 Corrado D, Thiene G, Nava A, Rossi L, Pennelli N. Sudden death in young competitive athletes: clinicopathologic correlations in 22 cases. Am $₹$ Med 1990;89: 588-96.

5 Thiene G, Nava A, Angelini A, Daliento L, Scognamiglio R, Corrado D. Anatomoclinical aspects of arrhythmogenic right ventricular cardiomyopathy. In: Baroldi G, Camerini F, Goodwin JF, eds. Advances in cardiomyopathies. Berlin: Springer-Verlag, 1990:397-408.

6 Fontaine G, Frank R, Fontaliran F, Lascault G, Tonet J. Right ventricular tachycardias. In: Parmley WW, Chatterjee X, eds. Cardiology-Physiology, Pharmacology, Diagnosis. JB Lippincott Company, New York, 1992;71 $1-17$.

7 Manyari D, Klein G, Gulamhusein S. Arrhythmogenic right ventricular dysplasia: a generalised cardiomyopathy? Circulation 1983;68:251-7.

8 Webb J, Kerr C, Huckell V, Mizgala H, Ricci D. Left ventricular abnormalities in arrhythmogenic right ventricutricular abnormalities in arrhythmogenic righ

9 Pinamonti B, Sinagra G, Salvi A, Di Lenarda A, Morgera $T$, Silvestri F, Bussani R, Camerini F. Left ventricular involvement in right ventricular cardiomyopathy. $\mathrm{Am}$ Heart $\mathcal{F}$ 1992;123:711-24.

10 Blomstrom-Lundqvist C, Sabel K-G, Olsson SB. A long term follow up of fifteen patients with arrhythmogenic right ventricular dysplasia. $B r$ Heart $\mathcal{f}$ 1987;58: 477-88.

11 Laurent $M$, Descaves C, Biron Y, Deplace C, Almange C, Daubert JC. Familial form of arrhythmogenic right ventricular dysplasia. Am Heart f 1987;113:827-9.

12 Nava A, Thiene G, Canciani B, Scognamiglio R, Daliento L, Buja G, Martini B, Stritoni P, Fasoli G. Familial occurrence of right ventricular dysplasia. A study involving nine families. $千$ Am Coll Cardiol 1988;12:1222-8.

13 Thiene G, Corrado D, Nava A, Rossi L, Poletti A, Boffa GM, Daliento L, Pennelli N. Right ventricular cardiomyopathy: Is there evidence of an inflammatory aetiology? Eur Heart $\mathcal{f}$ 1991;12:22-5.

14 Lobo FV, Heggtveit HA, Butany J, Silver MD, Edwards JE. Right ventricular dysplasia: morphological findings in 13 cases. Can $¥$ Cardiol 1992;8:261-8.

15 Fontaliran F, Fontaine G, Fillette F, Aouate P, Chomette $G$, Grosgogeat $Y$. Frontières nosologiques de la dysplasia arhythmogène. Variations quantitatives du tissu adipeux ventriculaire droit normal. Arch Mal Coeur 1991;84:33-8.

16 Nava A, Thiene G, Canciani B, Martini B, Daliento L, Buja GF, Fasoli G. Clinical profile of concealed form of arrhythmogenic right ventricular cardiomyopathy 
presenting with apparently idiopathic ventyricular arrhythmias. Int $f$ Cardiol 1992;35:195-206.

17 Robertson JH, Bardy GH, German LD, Gallagher JJ, Kisslo J. Comparison of two-dimensional echocardiographic and angiographic findings in arrhythmogenic right ventricular dysplasia. Am $f$ Cardiol 1985;55: right ventr.

18 Foale RA, Nihoyannopoulos P, McKenna WJ, Kleinebenne A, Nadazdin A, Rowland E, Smith G. Echocardiographic measurement of the normal adult right ventricle. $\mathrm{Br}$ Heart $\mathcal{F}$ 1986;56:33-44.

19 Scognamiglio R, Fasoli G, Nava A, Buja GF. Twodimensional echocardiographic features in patients with spontaneous right ventricular tachycardia without apparent heart disease. F Cardiovasc Ultrasonogr 1987; 6:113-8.

20 Blomstrom-Lundqvist C, Beckman-Suurkula $M$, Wallentin I, Jonsson R, Olsson SB. Ventricular dimensions and wall motion assessed by echocardiography in patients with arrhythmogenic right ventricular dysplasia. Eur Heart F 1988;9:1291-302.

21 Drobinsky G, Verdière G, Fontaine GH, Frank $R$, Fechner J, Grosgogeat Y. Diagnostic angiocardiographique des dysplasies ventriculaires droites. Arch Mal Coeur 1985;78:544-51.

22 Daubert C, Descaves C, Foulgoc JL, Bourdonnec C, Laurent $\mathrm{M}$, Gouffault J. Critical analysis of cineangiographic criteria for diagnosis of arrhythmogenic right ventricular dysplasia. Am Heart f 1988;115:448-59.

23 Daliento L, Rizzoli G, Thiene G. Diagnostic accuracy of right ventriculography in arrhythmogenic right ventricular cardiomyopathy. Am $\mathcal{f}$ Cardiol 1990;66:741-5.

24 Angelini A, Thiene G, Boffa GM, Calliari I, Daliento L, Valente $M$, Chioin $R$, Nava A, Dalla Volta S Endomyocardial biopsy in right ventricular cardiomyopathy. Int f Cardiol 1993;40:273-82.

25 Ricci C, Longo R, Pagnan L, Dalla Palma L, Pinamont B, Camerini F, Bussani R, Silvestri F. Magnetic resonance imaging in right ventricular dysplasia. $A m \mathcal{f}$ Cardiol 1992;70:1589-95.

26 Hamada S, Takamiya $M$, Ohe T, Ueda H. Arrhythmogenic right ventricular dysplasia: evaluation with electron-beam CT. Radiology 1993;187:723-7.

27 Fontaine G, Frank R, Gallais-Hamonno F, Allali I, Phan-Thuc H, Grosgogeat Y. Electrocardiographie des potentiels tardifs du syndrome de post-excitation. Arch potentiels tardifs du syndrom
Mal Coeur 1978;71:854-64.

28 Blomstrom-Lundqvist C, Olsson SB, Edvardsson $\mathrm{N}$. Follow-up by repeated signal-averaged surface QRS in patients with the syndrome of arrhythmogenic right ventricular dysplasia. Eur Heart $\mathcal{f}$ 1989;10(suppl D):54-60.

29 Canciani B, Nava A, Martini B, Buja GF, Thiene G. Signal-averaged electrocardiography in arrhythmogenic right ventricular cardiomyopathy (arrhythmogenic right ventricular dysplasia). New Trends in Arrhythmias 1992: 513-7. 